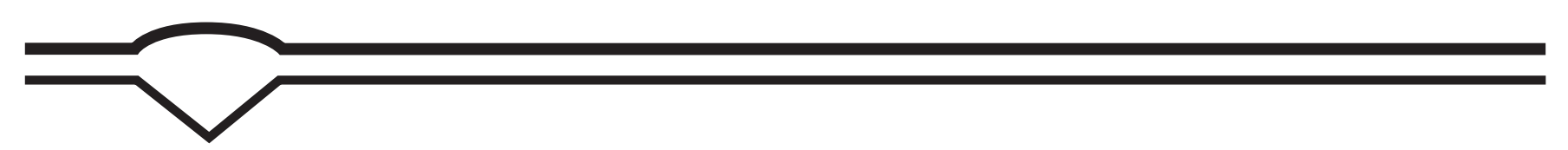

\title{
Directed differentiation of embryonic stem cells: Genetic and epigenetic methods
}

\author{
K. SUE O'SHEA, PhD
}

Embryonic stem cells are derived from the inner cell mass of the pre-implantation blastocyst, and can both self-renew and differentiate into all the cells and tissues of the body. The embryonic stem cell is an unsurpassed starting material to begin to understand a critical, largely inaccessible, period of development, as well as an important source of cells for transplantation and gene therapy. Despite their potential, attempts to obtain specific cell types from embryonic stem cells have been only partially successful because many of the growth factor combinations and developmental control genes involved in cell type restricted differentiation are unknown. This article summarizes some of the recent advances in promoting lineage restricted differentiation of embryonic stem cells, focusing on growth factor manipulation, or genetically altering embryonic stem cells to produce a desired phenotype. The two approaches epitomize current scientific concerns regarding the therapeutic use of these cells; genetic alterations will produce more pure cells with the risk of increasing the likelihood of malignant transformation; epigenetic methods for the manipulation of stem cell phenotype are often incomplete and remaining pluripotent cells are likely to form teratomas. As more is known about lineage specification during development, it will be possible to more precisely control cell type specification. (WOUND REP REG 2001;9:443-459)

Cell-cell contact, position in the embryo, and exposure to a variety of (many yet unknown) growth and differentiation signals, combine to initiate the expression and repression of cascades of genes that shape the developing embryo. While there has been considerable progress in understanding the molecular basis of morphogenesis, it is clear that many developmental control genes have not yet been identified and basic questions regarding lineage specification are still unanswered. Because of the difficulty of manipulating the mammalian embryo, researchers have employed cell lines with multilineage potential as models of this critical phase of development.

From the Department of Cell and Developmental Biology, University of Michigan Medical School, Ann Arbor, Michigan.

Reprint requests: $K$. Sue O'Shea, PhD, Department of Cell and Developmental Biology, University of Michigan Medical School, 4748 MSIl Building, Ann Arbor, MI 48109-0616. Fax: (734) 763-1 166; Email: oshea@umich.edu.

Copyright (c) 2001 by The Wound Healing Society.

ISSN: 1067-1927\$15.00+0

\begin{tabular}{|ll|}
\hline BMP & Bone morphogenetic protein \\
DMSO & Dimethyl sulfoxide \\
EBs & Embryoid bodies \\
EC & Embryonal carcinoma \\
EG & Embryonic germ \\
EGFP & Enhanced green fluorescent protein \\
ES & Embryonic stem \\
FGF & Fibroblast growth factor \\
hES & Human ES \\
HGF & Hepatocyte growth factor \\
Id & Inhibitor of differentiation \\
LIF & Leukemia inhibitory factor \\
MEF & Mouse embryonic fibroblast \\
RA & Retinoic acid \\
RT-PCR & Reverse transcriptase-polymerase chain \\
& reaction \\
\hline
\end{tabular}

\section{PLURIPOTENT CELL LINES Embryonal carcinoma cells}

Pluripotent cell lines have been defined by their origin; embryonal carcinoma (EC) cells are derived from spontaneous teratocarcinomas (testicular and ovarian). Teratocarcinoma cell lines have also been produced by grafting 
normal blastocysts or fetal gonadal ridges into adult mice, dissociation of the malignant teratocarcinomas, and passage of resulting cell lines. ${ }^{1}$ EC cells are pluripotent and have been shown to integrate into the mouse germ line, albeit with low frequency. ${ }^{2}$ Many of the lines have restricted developmental potential and can form only one or two differentiated derivatives, ${ }^{3,4}$ while others, interestingly, are nullipotent and form only teratomas. ${ }^{5}$ EC cells have been widely employed as important models of lineage segregation during differentiation and in the study of growth factor-mediated differentiation. ${ }^{6}$ Unlike ES cells (below) that must be constantly passaged to inhibit differentiation, EC cells typically must be stimulated to differentiate.

\section{Embryonic germ cells}

A second class of pluripotent cell has been developed by "reprogramming" primordial germ cells, which are destined to form egg and sperm, into pluripotent embryonic germ (EG) cells by culture in medium containing leukemia inhibitory factor (LIF), stem cell factor, and fibroblast growth factor-2 (FGF-2). 7,8 These cells have been shown to contribute to the germ line in transgenic animals, ${ }^{9}$ but appear to have limited growth and differentiation capabilities. Both mouse ${ }^{8,10}$ and human ${ }^{11,12}$ EG cell lines have been developed and have been differentiated as embryoid bodies into many cell types. ${ }^{13}$

Like tissue stem cells, it is likely that each will be useful in addressing specific questions regarding embryonic development; for example, EG cells may be particularly useful in studying the loss/maintenance of methylation marks during differentiation. ${ }^{10}$

\section{Embryonic stem cells}

In the early 1980s, several laboratories derived cells from the 3.5 day mouse blastocyst inner cell mass ( $\sim 50$ cells) into tissue culture (Figure 1) by growing them on feeder

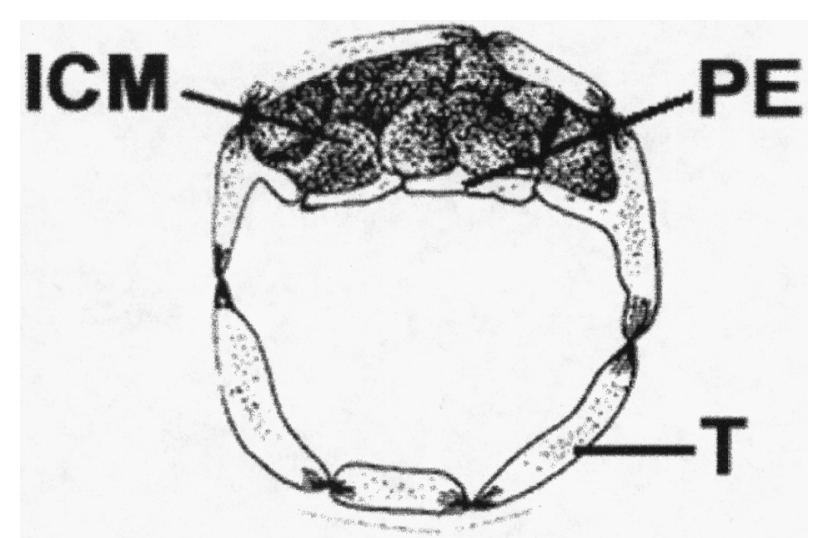

Figure 1. Schematic view of day 4 blastocyst. ICM $=$ Inner cell mass; $\mathrm{T}=$ Trophoblast; $\mathrm{PE}=$ Primitive endoderm. cell layers or in conditioned medium that we now know contained the inhibitor of differentiation, LIF. ${ }^{14-16}$ Since that time, ES cells have been derived from a number of other species ${ }^{17}$ including the human blastocyst. ${ }^{18,19}$ Mouse ES cells have been most extensively studied. They were initially used primarily to create null mutations in mouse embryos via gene targeting and homologous recombination, and more recently have also been employed as a model system to understand lineage differentiation and as a source of cells for transplantation.

ES cells exhibit all of the characteristics of a "stem cell," including long-term self-renewal. Unlike most tissue stem cells, but see $^{20}$ when combined with normal blastocysts, ES cells can differentiate into all cell types in vivo and into many derivatives in vitro. ${ }^{21} \mathrm{ES}$ cells have high levels of telomerase activity, ${ }^{22}$ have a very short G1 cell cycle checkpoint, and initiate DNA replication without external stimulation..$^{23}$ Because they are widely available and because technologies have been developed to delete, replace, or overexpress genes of interest, ES cells provide a very powerful means to study an otherwise largely inaccessible period of development.

ES cells are also a tremendous source of cells for gene and cell replacement therapies, particularly if the differentiation of the ES cell can be precisely controlled. While the three-dimensional changes that shape the early embryo from blastocyst to muscle cell are relatively well defined, surprisingly little is known about the molecular genetic events that occur as the blastocyst differentiates. Although it makes no cellular contribution to the embryo proper, the transient primitive endoderm, which separates the epiblast from the blastocoele, produces factors which may control both survival ${ }^{24}$ and differentiation of the inner cell mass and epiblast. ${ }^{25}$ Among those genes expressed in the primitive endoderm that have a critical function in differentiation are members of the GATA family of transcription factors, particularly GATA- 4 and GATA$6,{ }^{26,27} \mathrm{Stat} 3,{ }^{28}$ and many genes which play a role in axis formation and gastrulation, including bone morphogenetic proteins (BMPs), fibroblast growth factors (FGFs), cerberus, cripto, and members of the forkhead and Hex gene families.

\section{DIFFERENTIATION PARADIGMS Aggregation mediated differentiation (embryoid bodies)}

Because mutation of many of these early genes results in a lethal phenotype (at or before gastrulation), gene targeted ES (-/-) have been differentiated in vitro, to determine if the mutated gene is required for the formation of a particular tissue type. Many studies that have 
examined the role of factors produced by the primitive endoderm have therefore relied on the differentiation of ES cells in suspension culture, where an outer layer of mixed visceral and parietal endoderm surrounds a large aggregate of differentiating cells. ${ }^{14,29}$ After several days in vitro, these aggregates (termed embryoid bodies [EBs] because of the presence of many early embryonic derivatives, [Figure 2]) are surrounded by a layer of endoderm which expresses markers of the visceral endoderm $(\alpha-$ fetoprotein, apical localization of villin, dolichos biflorus lectin binding) and with additional time in vitro, a lumen reminiscent of the pro-amniotic cavity forms within the aggregate (cystic embryoid body). In some ways EBs do resemble the early egg cylinder staged embryo, with an outer endoderm layer and an inner primitive ectoderm, which differentiates to mesenchyme and other derivatives. Within the aggregate, a variety of cell types can be identified histologically or using cell type-specific antibodies.

EBs form in confluent cultures by overgrowth of ES cells following removal of LIF from the culture medium, when ES cells are cultured in untreated tissue culture dishes (Petri dishes), or in conditions of low substrate interaction (e.g., methylcellulose culture). These culture conditions typically produce relatively large, uneven aggregates of cells. More precise control can be obtained by placing known numbers of cells (typically 500-1000) in hanging drop cultures. We have grown ES on tissue culture plastic that has been rendered low adhesive by exposure to UV light to cross link the proprietary protein coatings on the tissue culture dish surface. After 18-24 hours of culture on UV cross-linked dishes, uniform EBs lift from the surface of the dish. This technique can also be used to create patterned substrates with regions of high and low adhesivity. ${ }^{30}$

EBs have been cultured in the presence/absence of retinoic acid (RA), in defined medium or medium also containing serum, or with additional growth factors to promote differentiation. After various times in vitro, EBs can be examined to determine the types of cells present or they can be dissociated and cultured further to increase the purity of derived cells. EB formation has been particularly useful in studying the process of apoptosis and cavitation, ${ }^{31}$ in epithelial morphogenesis, ${ }^{32}$ and in studying the role of endoderm specific genes. When a null mutation has resulted in a prenatal lethal condition due to pleiotrophic effects of the gene, EB have shown that the gene is or is not critical for the differentiation of a particular lineage.

The pattern of gene expression in differentiating EBs generally recapitulates that seen in vivo in the early postimplantation period, ${ }^{33,34}$ with sequential expression of germ layer specific genes. ${ }^{35}$ However, differentiation in the center of a conglomerate of cell types-some differentiating, some undergoing apoptosis, all secreting signaling molecules-bears little similarity to the precise waves of differentiation that shape the intact embryo. Despite the mixture of growth and death factors, normal and atypical cell contacts, the interior of the aggregate is apparently well oxygenated. ${ }^{36}$ However, in another study, simply dissociating the EBs produced a 3.5-fold increase in the number of differentiated derivatives (nestin + CNS progenitors). ${ }^{37}$

When differentiated cells were removed from EBs by growing ES cells transfected to express the neomycin phosphotransferase gene under the control of the stem cell-restricted Oct-3/4 promoter in high levels of antibiotic, the outer layer of visceral endoderm and differentiating cells within the EB were removed, and there was an expansion of pluripotent stem cells in conditions that would otherwise have promoted their differentiation (LIF-). These results suggest that differentiating cells, particularly the visceral endoderm, may be responsible for initiating differentiation within the EB. ${ }^{38}$

Although EBs have been a useful model of development, a test of differentiation potential following mutation of a critical gene, and have produced populations of cells "enriched" for a particular lineage, differentiated cells must somehow be separated prior to studies of gene expression from pooled RNAs, and prior to implantation since continued proliferation of stem cells present at the center of the aggregate ${ }^{39}$ may result in tumor formation.

\section{Nonspecific differentiating agents}

Despite its widespread use in ES cell differentiation paradigms, relatively little is known regarding the molecular basis of the teratogenic/morphogenetic effects of retinoic acid (RA), although it has been assumed that its pleiotrophic effects are determined by combinations of RA receptor (RAR) and retinoid $\mathrm{X}$ receptor (RXR) receptors expressed by differentiating cells. ${ }^{40}$ Based on the expression of RA in signaling regions in the early embryo ${ }^{41}$ and its ability to pattern tissues in a gradient, ${ }^{42}$ it has been suggested that gradients of RA present in the early embryo may control gene expression patterns during morphogenesis. Thus, RA concentration has been shown to determine which cell types differentiate in vitro from EC cells ${ }^{43}$ with higher levels $\left(10^{-7} \mathrm{M}\right)$ producing neurons and glia and lower levels $\left(10^{-9} \mathrm{M}\right)$ stimulating the differentiation of cardiac muscle. In embryos, RA causes skeletal duplications and defects, and it has recently been shown that 3 ' HOX genes (many contain RA-responsive elements) are activated at lower concentrations compared with those located more $5^{\prime} .44,45$ 

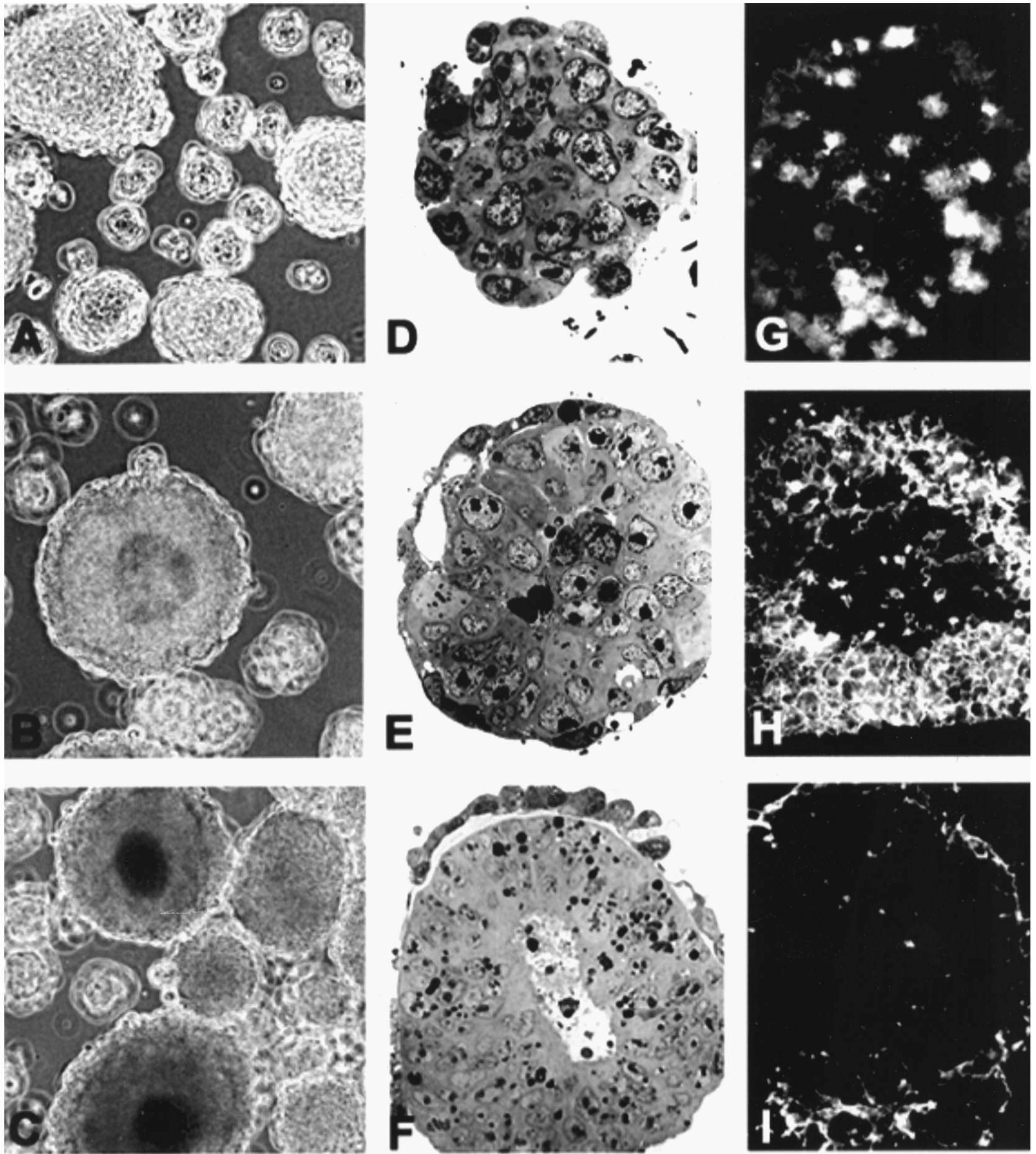

Figure 2. Embryoid bodies formed by suspension culture in defined medium. (A-C) Phase-contrast micrographs illustrating the increasing complexity of the EB, from a simple aggregate of cells at 24 hours (A), formation of an outer endoderm layer and beginnings of a lumen at 48 hours (B), to aggregates with fluid-filled centers (cystic embryoid bodies) after 72 hours (C) in N2 medium. Embryoid bodies were embedded in resin and $1 \mu \mathrm{m}$ sections cut and stained to illustrate the cellular reorganization within the EB over the 72 hours culture period. (D) After 24 hours, endoderm is just beginning to cover the aggregate. (E) After 48 hours in vitro, endoderm surrounds the aggregated cells, and cells undergoing apoptosis are present at the center. (F) After 72 hours in vitro there is an "epithelial" organization to the EB, a fluid-filled lumen, and an outer layer of endoderm-like cells. Immunohistochemical localization of cell type-specific antibodies indicates that many of the aggregated ES cells continue to express the stem cell marker SSEA-1 after 24 hours in suspension (G). E-Cadherin is expressed by cells outlining the forming lumen at 48 hours $(H)$, and a well-formed basement membrane containing laminin is present after 72 hours in vitro (I). Secondary antibodies - FITC. 
In a careful study of the differentiation of ES cells in response to RA, Rohwedel et al. ${ }^{46}$ showed that both the concentration of RA and stage of differentiation at the time of exposure determine the cell types derived from EBs. Early exposure (days 1-2) produced neurons and inhibited the formation of cardiomyocytes; exposure on days 2 to 5 produced skeletal muscle cells, neurons, and adipocytes; ${ }^{47}$ while exposure after 5 days in vitro induced cardiac and vascular smooth muscle at the expense of skeletal muscle differentiation. These authors suggest that the effects of RA could result from its ability to alter positional fate.

These observations are consistent with those of Fraichard et $\mathrm{al}^{48}$ who obtained neurons following exposure on days 1-2 of EB formation, as well as those of van Inzen et al., ${ }^{49}$ who reported that exposure of ES cells to RA without aggregation is sufficient to induce expression of the neuronal markers, neurofilament-medium, and GAP-43. However, the most widely employed paradigm to obtain neurons from ES cells relies on 4day aggregation without stimulation, followed by an additional 4 days in suspension in the presence of $\mathrm{RA}$ $(4-, 4+)^{50}$ followed by plating. Neurons also form from human ES cells aggregated for 5 days followed by dissociation and 10-day exposure to RA. ${ }^{51,52}$

Dimethyl sulfoxide (DMSO) has also been employed to induce differentiation of ES cells. The addition of 0.1\% DMSO to EBs cultures enhanced skeletal muscle differentiation, ${ }^{53}$ while Lako et al ${ }^{54}$ have shown that exposure of EB to 1\% DMSO significantly enhanced the commitment of ES cells to the hematopoietic pathway, with $80 \%$ of DMSO-exposed EBs containing hematopoietic foci compared with $42 \%$ of controls. RA $\left(10^{-8} \mathrm{M}\right)$, on the other hand, reduced hematopoietic commitment to $18 \%{ }^{54}$ RA and DMSO are most commonly used to stimulate ES cell differentiation, although compounds such as 5azacytidine, which demethylates CpG islands and activates gene expression, have been used to promote differentiation of other cell lines such as fibroblasts. ${ }^{55}$

\section{GENETIC MANIPULATION OF ES CELLS}

Gene targeting has been used extensively in the mouse, most typically to introduce null mutations into a particular gene using homologous recombination in ES cells, ${ }^{56}$ to determine the role of that gene in development, or to create mouse models of human disease. Transgenic animals in which the gene of interest drives the expression of a tracer (typically beta-galactosidoase) have been used extensively to monitor gene expression during development, while overexpression of a gene (knock-in) to create mice or embryos has not been as widely employed (but see overexpression of the insulin-like growth factor I, ${ }^{57}$ production of models of neurological disease $\beta$-amyloid, ${ }^{58}$ overexpression of the proto-oncogene $v$-src. ${ }^{59}$ ) ES cells have also been used to screen for stage-specific and lineage-restricted genes using entrapment vector insertion strategies, ${ }^{35}$ exon or promoter trap constructs, ${ }^{60}$ or secretory trap mutagenesis to identify cell signaling pathways in development. ${ }^{61}$ ES cells have also been used to identify genes downstream of the stem cell-restricted Oct-3/4 gene using suppression-subtractive hybridization analysis $^{62}$ or genes expressed in response to specific growth factors by mouse ${ }^{63}$ or human ${ }^{52}$ ES cells. Human mini-chromosomes have also been successfully introduced into mouse ES cells ${ }^{64}$ as a prequel to engineering artificial chromosomes into the mouse germline.

Differentiation of gene-targeted ES cells typically requires conversion of the ES cells from $+/-$ to a null genotype $^{65}$ and has been employed to determine the effects of an embryo-lethal gene deletion on cell type-specific differentiation. For example, mutation of the huntingtin gene is lethal at e7, well before neurogenesis, but apparently normal neurons differentiate from null ES cells. ${ }^{66}$ While these paradigms offer the potential to determine if a targeted gene is critical to the development of a particular derivative, many null lines grow extremely poorly in vitro, or not at all.

Another effective use of ES cells has been to transfect cells to express a marker, such as the enhanced green fluorescent protein (EGFP), either constituitively ${ }^{67}$ or under the control of a lineage-restricted gene. As ES cells differentiate in vitro and the lineage-specific gene is expressed, so is the EGFP, and differentiated cells of the desired lineage can be identified. This technique can be quite effective when the selected gene is expressed at relatively high levels in all differentiated progeny. Cardiac myocytes were isolated using the cardiac $\alpha$ actin promoter to express EGFP ${ }^{68}$ while Pratt et al ${ }^{69}$ produced ES cells that express EGFP via the tau promoter, a resource for neuronal transplantation and study of axonal outgrowth and regeneration. Eiges et al. ${ }^{39}$ developed a human ES line in which the stem cell-restricted gene Rex-1 drives expression of EGFP. Thus, as stem cells differentiate and down-regulate Rex-1 expression, EGFP expression is lost from the cells, creating a system to identify and sort pluripotent cells.

\section{Lineage selection}

Lineage selection has also been employed to develop highly purified populations of cells. Lineage selection, or selective ablation of cells not expressing a lineage restricted gene, produces a very pure population (98-99\%) of cells, but relies on continued expression by the cells of 
the particular promoter construct, or transient selection during its window of expression. ${ }^{70} \mathrm{McWhir}$ et al. ${ }^{71}$ used this selection method to develop a line of ES cells from the nonpermissive CBA mouse strain. The stem cellrestricted gene Oct-3/4 was used to express the antibiotic resistance gene neomycin phosphotransferase. When blastocysts expressing this vector were grown in antibiotic containing medium, only ES cells (Oct-3/4 +) survived. Mountford et al..$^{38}$ expressed a similar construct in ES cells to demonstrate that selective ablation of differentiated cells in EBs produce aggregates composed of proliferating ES cells, even in conditions that promote their differentiation (see discussion above).

Lineage selection has also been employed to produce nearly homogeneous populations of cardiac muscle cells by transfecting ES cells with the cardiac $\alpha$ myosin heavy chain promoter fused to the neomycin phosphotransferase gene. When stably transfected cells were differentiated as EBs, then selected in antibiotic, $99.6 \%$ of the surviving cells were cardiomyocytes, which were functional based on their successful integration into the ventricular myocardium of $m d x$ mice..$^{72}$ Using a similar approach, $\mathrm{Li}$ et al. ${ }^{73}$ placed a neomycin resistance cassette in the Sox2 gene locus (Sox1,2 are expressed in the early neuroepithelium) ${ }^{74} \mathrm{ES}$ cells were differentiated using conditions that promote development of neurons, then exposed to G418 to select for neuroepithelial progenitors expressing Sox2 (and neo), producing cultures highly enriched in neuronal cells.

While lineage selection techniques are very efficient in obtaining purified cell types, differentiation as aggregates is heterogeneous, with some cells differentiating more rapidly than others. The concern, then, is that the selection gene (particularly one expressed in "progenitors" rather than differentiated derivatives) will be transiently expressed by the cells so that the selection window becomes very narrow. Lineage selection is an excellent approach to deriving cells of a particular phenotype, but if the goal is to examine, for example, growth factor responsiveness of the cells, differentiation as an aggregate will expose ES cells to multiple (uncontrolled, in fact unknown) growth and differentiation signals. Because many cells will not express neo, selection will expose the ES cells to additional cytokines, caspases, etc., released by apoptotic cells.

When the culture conditions (or growth factors) that will induce the expression of a particular lineage selection gene are known, transfection of ES cells with promoters/enhancers to express an antibiotic resistance gene can produce lines of progenitor cells for additional studies of growth factor-, substrate-, etc., mediated differentiation. We have used this technique to develop neuro- epithelial progenitor cells by using the second exon (CNS specific) of the nestin gene to express neo in ES cells. ${ }^{75}$ Nestin is an intermediate filament protein expressed in the developing nervous system and in neural stem cells, which is down-regulated with differentiation. ${ }^{76}$ It is reexpressed following injury, and is widely used as a marker for neural stem cells. We transfected ES cells with this expression vector, selected lines in G418 (300 $\mathrm{U} / \mathrm{ml}$ ), and expanded and characterized over 40 resulting clones. Because it is known that culture of ES cells in defined medium induces the expression of nestin, ${ }^{77}$ it has been possible to develop "lines" of nestin-expressing ES cells by growing them in defined medium in the presence of LIF and G418 antibiotic. Thus, differentiating cells are removed by the G418, and nestin-expressing, mitotically active cells survive. These cells can be removed from G418 selection and the effects of growth factors on cell type-specific differentiation (particular neurotransmitter expressing, or glial lineages) can be determined (Figure 3). These cell lines cannot be differentiated and then selected (as in the Klug ${ }^{72}$ and $\mathrm{Li}^{73}$ examples), because the nestin gene is down-regulated with differentiation of neuronal cells, so these cells are killed in G418. Growth factor-mediated differentiation of nestinneo cells progresses over 3 to 4 days in vitro; considerably more rapid than other differentiation techniques which rely on selection of nestin + cells in defined medium after 12 days in vitro.

Soria et al. $^{78}$ used a similar transfection/selection process that they refer to as "cell trapping." They first transfected ES cells with the human insulin gene promoter driving hygromycin expression. Cells were selected and differentiated, producing insulin-secreting cell lines. When clusters of these cells were implanted into the spleen of mice with induced diabetes, they corrected both the hyperglycemia and body weights (below).

Lineage selection approaches are generally appropriate if the goal is to obtain large numbers of highly purified cells for example, for transplantation to damaged tissues. However, if the goal is to develop "cell lines" to study growth factor effects on lineage segregation, because many of the genes that have been chosen are expressed in mature rather than transient populations, the resulting cells have already completed their lineage choices and typically are post-mitotic.

\section{Forced differentiation of ES cells}

Another method to obtain cells of a particular lineage is to overexpress a gene believed to be critical to the development of a specific cell type (typically without antibiotic selection, constituitive expression). For example, overexpression of the muscle-specific bHLH factor 

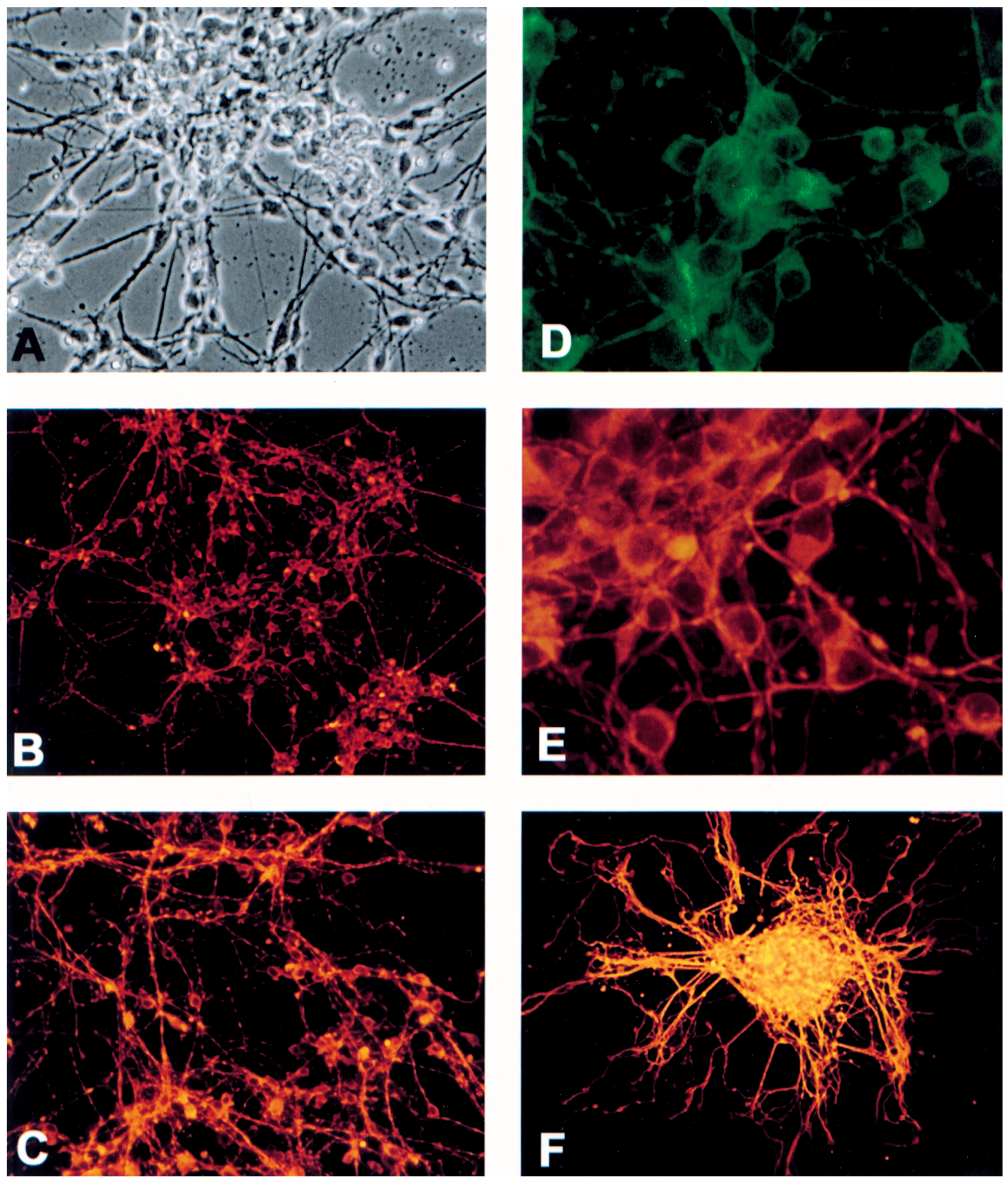

Figure 3. Neuronal differentiation of the nestin-neo cell lines. Expression of the nestin enhancer driving expression of the neomycin phosphotransferase gene allowed us to select a number of ES cell lines that resemble neural progenitors. (A) After 72 hours in vitro, there is extensive neuronal differentiation of these cells as indicated by their morphological appearance, (A) by phase contrast, or (B) by their expression of neuronal markers (anti-TUJ1 antibody, Cy3 secondary). When exposed to FGF-8b, there was widespread neuronal differentiation in these cultures (C). (D, E) High-magnification images of these cells. Because the parent line was derived from the B5 EGFP mouse, ${ }^{67}$ ES cells continue to express EGFP as they differentiate, e.g., D (no stain), so they can be easily traced for transplantation studies. Immunohistochemical localization of neuronal tubulin (anti-TUJ1 antibody, Cy3 secondary) illustrates the extensive neuronal differentiation of an aggregate of nestin-neo ES cells exposed to FGF-8b. (F) Differentiation of the nestin-neo progenitors is much more rapid and more complete than that of the B5 or D3 parental lines. Exposure to FGF-8b also caused some fasciculation of neuronal processes, as illustrated here. 
MyoD in ES cells produced widespread differentiation of skeletal muscle cells, which fused to form contractile myotubes. ${ }^{79}$ Alternatively, constituitive expression of the $m$-twist gene, which codes for a bHLH protein that mediates binding to the E-box present in many musclerestricted genes, in ES cells differentiated as EBs, inhibited the formation of myogenic cells in a dose-dependent manner, ${ }^{80}$ demonstrating that myogenesis is regulated by both muscle determination genes, myf5, 6 , myogenin, and MyoD, as well as inhibitory factors.

Overexpression in P19 EC cells of the GATA-4 zinc finger transcription factor thought to be a transcriptional activator of several cardiomyocyte-specific genes significantly increased (over 10X) cardiac muscle differentiation in resulting aggregates. ${ }^{81}$ In GATA-4-deficient EC cells, however, differentiation of "cardioblasts," but not endoderm or mesodermal derivatives, was inhibited, suggesting that GATA-4 may both initiate cardiac muscle differentiation and be a target of survival factors for precardiac cells. ${ }^{82}$

ES cells have also been employed to examine the maintenance of the methylation imprint during development, ${ }^{83}$ i.e., androgenetic ES cells are predicted to overexpress maternally imprinted genes while paternally imprinted genes are expected to be eliminated. ${ }^{84}$ Interestingly, differentiation of uniparental ES cells in vitro indicated that there was an overabundance of muscle cells. ${ }^{85}$ When ES cells were transfected to overexpress insulinlike growth factor-II, an autocrine growth factor for myoblasts and a gene expressed via the paternal allele, differentiating EB cells contained more myogenic cells than controls. ${ }^{86}$ Forced expression of the X-linked Pem gene resulted in ES cells that were unable to differentiate in $\mathrm{EBs},{ }^{87}$ suggesting a role for $\mathrm{Pem}$ in the transition between undifferentiated and differentiated cells in the embryo.

In one of the more elegant studies of this type, Niwa et al.$^{88}$ used a conditional system to express varying levels of the gene Pou $5 f$, which encodes the stem cell factor Oct-3/4, in ES cells. A less than twofold increase in Oct-3/ 4 produced endoderm and mesoderm, while trophoblast cells formed when Oct-3/4 expression was repressed. This is consistent with the normal embryonic expression of Oct-3/4 throughout the early preimplantation embryo, becoming restricted to the inner cell mass and its derivatives. ${ }^{89}$

Growth factor overexpression in ES cells is a hybrid between genetic and epigenetic manipulation, and given the need for repair, insulin, and neurotransmitter expression, it is surprising that more studies of this type have not yet been carried out. There is, however, the real possibility of autocrine differentiation of these cells, precluding the derivation of cell lines.

\section{GROWTH FACTOR-DIRECTED DIFFERENTIATION}

Because most differentiation protocols begin with an aggregation step, often in complete medium (serum + ) with RA or DMSO, the growth- and differentiation-promoting factors critical to very early steps in differentiation are unknown. Following aggregation (24 hours to 20 days), EBs are either plated directly or disaggregated and then plated in growth factor-enriched medium. Using these techniques, investigators have successfully produced a range of tissue types, including:

1. mesodermal derivatives (adipocytes, ${ }^{47}$ osteoblasts, ${ }^{90,91}$ chondrocytes, ${ }^{92}$ smooth muscle,${ }^{93}$ skeletal muscle,${ }^{94}$ cardiomyocytes, ${ }^{29,95}$ hematopoietic cells,,${ }^{96,97}$ mast cells, ${ }^{98}$ osteoclasts ${ }^{99}$ and endothelial cells, $, 93,100,101$;

2. ectodermal derivatives (keratinocytes, ${ }^{102,103}$ melanocytes, ${ }^{104}$ dendritic cells, ${ }^{105}$ neurons, ${ }^{50,51,106,107}$ glial cells both astrocytes ${ }^{48}$ and oligodendrocytes; ${ }^{108,109}$ ); and more recently

3. endodermal derivatives (liver, ${ }^{110}$ intestine, ${ }^{111,112}$ pancreatic islets ${ }^{78,113}$ ).

Although differentiation of ES cells into three primary germ layers has been reported since their derivation ${ }^{14}$ and remains the gold standard of pluripotentiality, ${ }^{11,18,19}$ there seems to be a propensity of ES cells to form ectodermal derivatives, particularly neurons. Whether this reflects lineage segregation within the epiblast, ${ }^{16}$ or whether culture conditions/growth factor combinations for neuronal differentiation are better defined ${ }^{114}$ than for other tissue types is not clear. Because of the very rapid developments in this field, an update regarding cell type differentiation not previously obtained (e.g., hepatocytes, islet-like cells), coderivation of tissues, or classical approaches, has been included here. There are many additional recent reviews of ES differentiation. ${ }^{115-118}$

\section{EMBRYONIC LINEAGE SEGREGATION: GENES EXPRESSED DURING GASTRULATION AND NEURAL INDUCTION}

Because they express genes typical of the primitive ectoderm, ${ }^{16} \mathrm{ES}$ cells are increasingly being employed to study lineage choice in early development, and have been suggested to be the mammalian equivalent of the amphibian animal cap system employed so successfully to study neural induction. ${ }^{119} \mathrm{ES}$ cells have been transfected to express cDNAs for noggin and chordin, ${ }^{120}$ or have been exposed to recombinant human noggin protein $^{121}$ or mouse chordin. ${ }^{122}$ Expression of these secreted signaling molecules by ES cells themselves has been most efficient 
in promoting their neuronal differentiation, with $>90 \%$ ES cells transfected with pCS2-noggin attaining a primitive neuronal phenotype after even brief (72-hour) culture periods. ${ }^{120}$ Stem cell marker genes are rapidly downregulated and pan-neuroepithelial markers and neurodetermination genes up-regulated. Exposure to human recombinant proteins was less efficient in promoting neuronal differentiation, ${ }^{121}$ which may be due to the surprisingly low homology between human and mouse proteins or the amount of protein present in these cultures. In all cases, addition of BMP4 (the extracellular target of these proteins) efficiently inhibited neuronal differentiation with formation of ectoderm-like cells. ${ }^{122,123}$ That this signaling pathway functions in ES cells as in amphibia is clear from the differentiation of gene-deleted ES cells, e.g., Smad 4 null cells (Smads transduce the inhibitory BMP signal to nucleus) differentiated into more neuronal cells. ${ }^{121}$ In $\beta 1$ integrin null ES cells, reduction in BMP4 expression has been suggested to be the basis for the widespread neuronal differentiation of the $\beta 1$ null cells. ${ }^{124}$

Hollnagel et al. ${ }^{63}$ have used differential display reverse transcriptase-polymerase chain reaction (RT-PCR) techniques to examine gene expression induced by BMP2/4 and identified a number of early target genes Msx-1,-2 as well as several Id genes (Inhibitors of differentiation; negative regulators of bHLH transcription factors) that are direct targets of BMP2/4. Interestingly, Id1,2,3 are up-regulated, but the nervous system-specific Id4 was not present in ES cells, nor was it expressed following BMP treatment. Claudin- 6 , one of the earliest epithelial restricted genes to be expressed in differentiating $\mathrm{EB}$, is inhibited by noggin protein. ${ }^{125}$ These results further support a role for the BMP4 signaling pathway in stimulating epidermal ectodermal differentiation and inhibiting neural differentiation.

\section{Endoderm}

Endoderm (villin +, GATA-4+) - visceral (and some parietal)—forms rapidly in suspension culture to cover the surface of aggregated cells, and some markers of earlyto mid-differentiation such as $\alpha$-fetoprotein and albumen are expressed in these cultures. However, rarely have more differentiated endodermal derivatives been identified. Recently, however, several groups have shown that ES cells produce insulin-both human ES cells, ${ }^{126}$ and mouse cells ${ }^{113}$-after extended time in vitro. Soria et al. ${ }^{78}$ transfected mouse ES cells with the human insulin gene promoter driving expression of the hygromycin gene, then selected cells in antibiotic. After differentiation as EBs, cells were dissociated, resuspended, and differentiated in the presence of nicotinamide and high glucose; then clusters of cells were implanted into the spleen of diabetic mice. Transplanted animals corrected the streptotocin-induced hyperglycemia and restored body weights without forming tumors after as long as 16 weeks.

Lumelskey et al. ${ }^{113}$ used a five-step program of aggregation, nestin-selection followed by growth factor (FGF2) expansion with the addition of nicotinamide, then differentiation. These cells released insulin in response to glucose stimulation and associated with neuronal cells into islet like clusters in vitro. Insulin secretion by these cells was low compared with beta cells, however. When implanted into rats with streptotocin-induced diabetes, ES-derived "islets" were unable to reverse the induced hyperglycemia, although implants were vascularized, and implanted animals survived longer than controls.

Hepatocytes have also recently been derived from ES cells ${ }^{110}$ by an 18-day culture paradigm in which ES are aggregated and then exposed sequentially to acidicFGF (hepatic maturation, 3 days), hepatocyte growth factor (midstage, 7 days), followed by late stage maturation stimulated by 4-day growth in oncostatin M, dexamethasone, with insulin, transferrin, and selenium. Although this study shows that ES cells can express genes typical of differentiated hepatocytes, there is no evidence that ES cell marker genes were down-regulated nor data on what other cell types are present in these cultures. In a forced differentiation approach to promote hepatocyte differentiation, the transcription factor HNF3 ( $\alpha, \beta$ subunits) was overexpressed in ES cells. With differentiation as EB, both induced expression of genes typical of early, but not late, endoderm. ${ }^{127}$

\section{Mesoderm}

Bone

To obtain bone-forming cells from ESs, a number of "osteogenic" supplements were applied to EB cells, including ascorbic acid, beta-glycerophosphate, BMP-2 and compactin, which increased the number of bone nodules formed compared with untreated EB cells. ${ }^{91}$ Another group applied the same cocktail of growth factors to ES cells or cocultured them with murine osteoblasts, ${ }^{90}$ resulting in the formation of bone nodules that expressed type-I collagen and osteocalcin. When added to cultures after 14 days of differentiation, dexamethasone, ascorbic acid and beta-glycerophosphate induced a fivefold increase in the number of bone nodules, coculture with osteoblasts a 14-fold increase compared with untreated ES cells.

\section{Co-derivation of tissues}

Clearly, a goal for transplantation studies is to produce tissues that are appropriately innervated and vascu- 
larized. To attain that goal, either differentiated cell types are implanted together, or immature cells are codifferentiated. (The assumption when immature cells are implanted is that growth factors in the environment will stimulate differentiation into region-specific, appropriate cell types, as has been shown for neural stem cells). To develop functional motor units, skeletal muscle and neurons were coderived in hanging drop cultures of ES cells, followed by growth on tissue culture plates. There was extensive colocalization of nicotinic acetylcholine receptor clusters with agrin and synaptophysin (markers of neuromuscular junction) in differentiating skeletal muscle myotubes. Neuromuscular junctions formed in close association with neuronal processes and were functional as assessed by patch clamping. ${ }^{128}$

Hematopoietic differentiation of ES cells is perhaps the most well defined lineage to form from ES cells. ${ }^{29,129-131}$ Differentiation in methylcellulose culture has been widely employed to obtain neutrophil, erythroid, mast cell, and macrophage lineages from ES cells. ${ }^{132}$ Transfer to animals genetically deficient in lymphocytes has shown their ability to reconstitute lymphocyte populations, ${ }^{133}$ and contrary to early results, ESderived cells do have multilineage hematopoietic reconstitution potential. ${ }^{134}$ ES cell differentiation has been widely employed to tease out the cascades of gene expression and growth factor requirements for these cells, although ES cells themselves contain RNAs for many known hematopoietic cytokines. ${ }^{130}$

It has recently been shown that overexpression of the LIM homeobox gene LH2 promotes the very early stages of hematopoiesis, ${ }^{135}$ and deletion of the marker CD34 gene in ES cells delays both erythroid and myeloid commitment. ${ }^{136}$ Exposure to Wnt3 protein was shown to increase in the number of EBs containing hematopoietic foci, ${ }^{54}$ suggesting new signaling pathways which may be involved in early lineage segregation of hematopoietic progenitors. Other mesodermal derivatives, particularly muscle cells, are described in the forced differentiation section above.

\section{Ectoderm}

Keratinocytes form in $\beta 1$ integrin null ES cultures, ${ }^{102}$ and basal keratinocytes are reported to be present in EBs developed by 20 days in suspension. ${ }^{103}$ In a combined approach, a keratinocyte-specific enhancer from the laminin $3 \alpha$ gene was ligated upstream of the keratin 5 promoter and EGFP; then the construct was electroporated into ES cells. Neo-resistant clones were selected and cells differentiated as EBs, resulting in the formation of foci containing labeled keratinocytes. ${ }^{103}$ This approach should expedite determination of the tissue culture con- ditions and growth factor requirements for keratinocyte differentiation, with obvious clinical applications.

Neurons, like hematopoietic cells, differentiate readily from mouse ES cells. Most differentiation protocols employ a 4-day aggregation step, followed by 4-day exposure to RA as aggregates $(4-, 4+),{ }^{50}$ although others have used growth factor-mediated differentiation, ${ }^{113,137,138}$ growth at clonal densities, ${ }^{121}$ and culture on the surface of a stromal cell line PA6 $6^{122}$ to promote neuronal differentiation. Measurement of action potentials generated by resulting cells has confirmed that differentiating neurons are functional. Neurons of GABAergic, dopaminergic, and serotonergic neurotransmitter phenotypes have been developed from ES cells using growth factor promoted differentiation.

With the goal of manipulating culture conditions and growth factor exposure to generate neuronal cells from ES cells, the McKay group has produced neurons characteristic of hindbrain (serotonergic) or midbrain (dopaminergic) regions. ${ }^{37}$ After aggregation, they selected nestin + progenitor cells by growth in defined medium (lineage selection), expanded the progenitors using FGF2, and exposed them to FGF-8b either alone or with Shh protein (based on the pattern of expression of these signaling molecules in developing brain $)^{139}$ and ascorbic acid. Using this culture paradigm, over $71.9 \%$ of the differentiated cells stained with antibodies to neuronal tubulin, TUJ1. Addition of ascorbic acid, Shh, and FGF-8b increased the number of dopaminergic neurons to $33.9 \%$ of all neurons, or $20 \%$ of the total number of cells present in the cultures. Under normal culture conditions, $0.8 \%$ of the derived neurons express serotonin. Exposure to Shh (with or without FGF8b) increased that number 14fold.

One concern with these approaches is that it is unclear what the remaining cell types are, because authors present RT-PCR data to show expression of targeted genes, but not of stem cell markers (to address culture purity) or markers of other phenotypes. In a study unique in that it combines RT-PCR and in situ hybridization analysis (so that the percentage and location of differentiated neurons can be ascertained), Renoncourt et al. ${ }^{140}$ demonstrate that RA treatment of EBs produces nestin-positive progenitors at the center of the aggregate, as well as neurons typical of ventral CNS, including both motoneurons and interneurons.

\section{Grafting of ES-derived neuronal cells}

When transplanted to the nervous system of normal or neurological mutants, ES cell-derived neuronal and glial cells incorporate well, although teratomas ${ }^{108,138,141}$ containing other cell types, including muscle and cartilage, 
form when EB rather than disaggregated cells are implanted. Deacon et al ${ }^{106}$ implanted ES cells differentiated with RA into adult mouse and rat striatum and into mouse kidney capsule. After 2 to 4 weeks, regardless of placement, grafts contained mixed populations of cells; most, however, had a dopaminergic or serotonergic phenotype. Interestingly, RA pretreatment had no effect on the lineages present in the graft. There was no regional specificity in which cell types were present in the graft, indicating that differentiation was cell autonomous rather than driven by local growth factors. This is not surprising considering that adult brain is largely growth factor poor, and EBs may produce sufficient growth and differentiation factors themselves to promote differentiation.

Benninger et al. ${ }^{141}$ demonstrated there was no effect of exposing EBs to growth factors (nerve growth factor, BDNF, or NT3) on in vivo differentiation of transplants. However, derivation of EBs in serum-free medium greatly decreased the number of non-neural cells after transplantation.

Oligodendrocytes (> 92\%) have also been produced using the 4-, 4+ method followed by growth in medium developed for glial cell differentiation, which contains NT3 and CNTF. ${ }^{142}$ There is an additional step in which loosely adherent cells (oligos) are separated from adherent astrocytes by shaking. Resulting cells are cultured as "oligospheres" followed by plating. Oligodendrocytes formed in this manner are able to myelinate axons in vitro, producing myelin sheathes with 10 to 15 layers after 9 days in vitro. Oligospheres were transplanted into the rat spinal cord that had been chemically lesioned (ethidium bromide or lysolecithin), or into shiverer mutant mice, which lack myelin basic protein (shi/shi). Although other cell types were apparently present, there were no tumors, and after 2 and 4 weeks in vivo, myelination of axon tracts was present for a distance of $0.5 \mathrm{~mm}$, with scattered foci as far as $2-3 \mathrm{~mm}$ from the injection site. ${ }^{109}$ While this study did not show recovery of function, a previous study by this group showed that transplantation of EBs formed by the 4-, 4+ method (without an oligosphere stage) into cord injured by contusion significantly improved locomotor function. ${ }^{143}$ However, the long-term survival of oligosphere implants and their effect on functional recovery remain to be determined.

Because neurodevelopmental and neurodegenerative disease may share common pathogenetic bases, ${ }^{144}$ ES cell differentiation may identify genes or susceptible cell types. These authors have examined lineage-specific expression of neural disease proteins in ES cells and EBs, and surprisingly, many neurological disease genes are expressed. For example, $\alpha$-synuclein (expressed in rare Parkinson's) is expressed in undifferentiated ES cells, then down-regulated. Other proteins associated with neurological disease such as frataxin (Frederich ataxia), ataxin 1 (spinocerebellar ataxia), and presenillin 2 (Alzheimer's disease) are expressed in differentiating EBs (but not undifferentiated ES cells), and are present in $\mathrm{O} 4+$ (oligodendrocytes) progeny. Neuronal differentiation of ES cells has shown that the widely expressed, developmentally important gene huntingtin is not essential for the differentiation of functional neurons ${ }^{66}$ suggesting that loss of functional huntingtin is not likely to produce the neurodegenerative changes in Huntington's disease. In our lab, Matt Lorinc ${ }^{145}$ has demonstrated that knock-in of trinucleotide repeats (CAG) into the HPRT locus of ES cells as a model of Huntington's disease results in a dose-dependent impairment in process outgrowth from differentiated neuronal cells. This paradigm provides an important model to study not only the pathogenesis of the neuronal changes in Huntington's, but also possible pharmacological amelioration, as well as the opportunity to identify downstream genes.

\section{SEARCH FOR ADDITIONAL DIFFERENTIATION MEDIATING FACTORS}

In addition to gene trap studies and comparison of differentially expressed RNAs, two "new" approaches are being employed to identify differentiation factors. The first relies on recapitulating the pattern of growth factor expression during development. For example, during hepatocyte differentiation, FGFs from the cardiac mesoderm induce liver primordium from foregut endoderm. These cells proliferate and migrate into the collagen-rich mesenchyme of the septum transversum, which secretes hepatocyte growth factor (HGF) to support primitive hepatocytes. During late fetal development the hematopoietic cells present in this region secrete oncostatin $M$ (OSM) which induces hepatocyte maturation. This pattern-growth of EBs, plating on collagen I, followed by sequential exposure to acidic FGF, HGF, and OSMinduced genes typical of late differentiation of liver. ${ }^{110}$ Differentiation of hindbrain- and midbrain-specific neurons was similarly based on regional patterns of growth factor expression during normal differentiation. ${ }^{39}$

A number of investigators have rediscovered the stromal cell as a source of growth factors to stimulate cell type-specific differentiation. ${ }^{146}$ Interestingly, in defined medium, the PA6 stromal cell line promotes differentiation of neuronal cells, ${ }^{122}$ while another line, ST2, specifically produced osteoclast differentiation.${ }^{99}$ In this study, the authors took the requisite step of identifying the cell surface bound and secreted growth factors required for osteoclast differentiation as macrophage colony- 
stimulating factor and the osteoprotegerin-ligand. When added directly to cultures, this combination induced widespread differentiation of osteoclasts. ${ }^{99}$ In a fusion of these two approaches, coculture of visceral endoderm with epiblast elicited hematopoiesis in the epiblast. ${ }^{147}$ These studies are reminiscent of the early derivation of ES cells in medium conditioned by fetal fibroblasts ${ }^{14}$ or Buffalo rat liver cells. ${ }^{148}$

\section{MARKERS}

Embryonic stem cells express a number of genes, which although not restricted to ES cells, are expressed only by undifferentiated ES cells and are useful to assess commitment to differentiation in a mixed population. These include the stage-specific embryonic antigen-1 (SSEA1), ${ }^{149}$ the transcription factor Oct-3/4 encoded by the Pou $5 f$ gene, ${ }^{150}$ Rex-1, ${ }^{151}$ and the neuronal restricted silencing factor (nrsf/REST). ${ }^{152}$ Many of the genes expressed by the inner cell mass or by the primitive ectoderm $^{16,25,153}$ could also be examined. In any differentiation paradigm, it is critical to show that stem cell markers are expressed at high levels in the starting population and are down-regulated with differentiation. This is critical to determine if there is a residual stem cell population that could either be unintentionally implanted, or via differential cell survival could selectively skew the results of differentiation experiments. Because culture of ES cells on gelatin induces the expression of some markers of differentiation, use of RNAs from blastocysts is an additional important control. Good markers of differentiated progeny must also be employed, as well as a panel of genes typical of multiple differentiated cell types, not only genes expected to be expressed by a single lineage.

Unfortunately, a universal marker of stem cells does not exist. CD34 class antigens have been useful to flow sort many types of hematopoietic stem cells, and factors that "license" cells to undergo replication may mark stem cells. Alternatively, many stem cells exclude Hoechst 33324. Unfortunately, none of these markers identifies all stem cell classes.

\section{DIFFERENTIATION OF HUMAN ES CELLS}

Mouse and human ES (hES) and EG cells share many similarities and important differences. ${ }^{112}$ Mouse ES and hEG cells grow as aggregates, while hES cells grow in a more dispersed fashion. All express high levels of telomerase activity, ${ }^{22}$ although mouse ES cells divide much more rapidly than hES ( 8 hour vs. 36 hour cell cycle). ${ }^{22}$

Mouse ES cells require addition of LIF to the culture medium to maintain their undifferentiated state, while hES must be grown on mouse embryonic fibroblasts (MEF) in the presence of bFGF, although some investigators believe that LIF helps maintain the hES cells undifferentiated as well. ${ }^{52}$ Recently, it has been possible to grow hES on matrigel-coated substrates rather than on MEFs, but medium conditioned by MEFs is required. ${ }^{154}$ Once the factor(s) produced by the MEFs have been identified, it will be possible to develop chemically defined media and potentially to derive hES cells without contact with mouse cells/products.

To date, few studies using the hES cell lines have produced purified populations ${ }^{51}$ or have been differentiated other than as aggregates. In benign teratomas formed by transplantation of EBs to nude mice or in $\mathrm{EB}$, many differentiating cell types and tissues have been identified. These include hair, keratinizing epithelium, respiratory epithelium, cuboidal epithelium, and wellorganized gut and glomeruli, as well as smooth muscle,

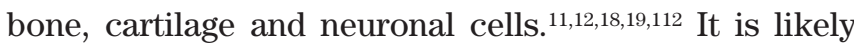
that additional cell types are present but are not organized into histologically identifiable tissues.

Odorico et al ${ }^{112}$ recently reported hematopoietic diferentiation of hES using a two-step differentiation protocol in which hES are initially cultured on the irradiated human bone marrow stromal cell line S17 in medium with fetal bovine serum but no additional growth factors. This was followed by methylcellulose culture, producing erythrocytes, macrophages, granulocytes and megakaryocytes. Interestingly, hES can also differentiate into trophoblast cells, ${ }^{112}$ making them a useful model of placentation and cell invasion.

In the most systematic approach, Schuldiner et al. ${ }^{52}$ applied a single concentration of each of eight growth factors-FGF-2, BMP4, epidermal growth factor, RA, transforming growth factor $\beta-1$, activin A, HGF and nerve growth factor-to H9 hES cells previously induced to begin differentiation by 5 day culture in suspension to produce EBs. EBs were disaggregated and the cells exposed to single growth factors for an additional 10 days. Lineage-specific differentiation resulted: FGF-2, BMP4, epidermal growth factor, RA-treated cultures contained ectoderm and mesoderm with FGF-2 promoting differentiation of keratin + epidermal ectoderm. Transforming growth factor- $\beta 1$ and activin A cultures contained mesoderm, activin A producing syncytia of muscle cells. HGF and nerve growth factor exposure resulted in gene expression patterns typical of all three cell layers. There are several questions regarding these results. First, what would happen if growth factor exposure had occurred before/during differentiation induced by growth as EBs? 
Second, the authors equate the presence of a particular derivative with inhibition of the development of other tissues. While that might be the case, it is equally possible that the particular factor was sufficiently potent to direct lineage differentiation preferentially into the observed lineage at the expense of (but not actively inhibiting development of) another lineage. These early results suggest that many of the pathways identified in other species appear to operate during these early inaccessible stages of human embryonic development. They may also suggest new pathways for development of a particular tissue type; i.e., both nerve growth factor and RA induced neuronal markers, but only RA caused expression of adrenal markers. A number of additional unpublished studies regarding the differentiation of $\mathrm{hES}$ are described in the recent NIH publication on stem cells. ${ }^{115}$

\section{CONCLUSIONS/FUTURE CHALLENGES}

Although there has been considerable progress in obtaining specific cell types from ES cells in the past few years, several basic concerns remain. The first is that while differentiated derivatives are more consistently obtained, and at higher frequencies than previously, few growth factor-mediated differentiation protocols promote the level of cell type restricted differentiation (>90\%) required for safe transplantation. Although it has been argued that genetic manipulation of ES cells increases the chance of malignant transformation and tumor formation, the chance of tumor formation following implantation of undifferentiated stem cells is perhaps even more significant. This is, in fact, the basic scientific divide between the use of epigenetic versus genetic methods to produce lineage-enriched cells for transplantation. If good growth factor selection methods could be established, they might be preferable to genetic approaches. However, although ES cells can be manipulated to secrete insulin, they produced significantly lower levels of insulin ${ }^{113}$ than those produced by genetically alterating ES cells. ${ }^{78}$

Because ES cells are easily transfected and selected, it would be possible to express a cell suicide gene under the control of, for example, a cyclin gene, so that if an implanted cell enters cycle, it is removed. Alternatively, an inducible promoter (e.g., tetracycline) could be used to express a lethal gene so that if implanted cells overexpress a particular growth factor or neurotransmitter they could be ablated.

Transplantation will also require either undesirable long-term immunosuppression, the development of "banks" of ES cells with differing population characteris- tics, or the deletion of MHC class I and II genes. ${ }^{12,117,155}$ While the latter approach has been widely touted to create "universal donor" ES cells, mice lacking MHC class I and II genes are able to mount a rejection response. ${ }^{156}$

It has also been suggested that replacement of an ES cell nucleus with a nucleus from a somatic cell (including fetal neurons) $)^{157}$ from a future recipient could create donor-matched ES cells for transplantation. ${ }^{158}$ While a similar approach was successful in producing Dolly, ${ }^{159}$ more than $90 \%$ of embryos produced by somatic cell nuclear transplantation are not viable. It appears that the genome-wide demethylation that occurs during early development to remove parental methylation marks may be incomplete in cloned cells, resulting in incomplete epigenetic reprogramming of donor DNA and abnormal methylation patterns. ${ }^{160}$

As our understanding of molecular embryology progresses, it should be increasingly possible to direct differentiation of pluripotent cells to a desired lineage. While there have been important advances in our understanding of lineage segregation during early development, the criteria by which a differentiated ES cell is labeled (e.g., a hepatocyte) must be more rigorous. Markers of terminal differentiation in RNAs extracted from a population of $10^{6}$ cells may well be present, but must be combined with analysis of other terminal markers, down-regulation of ES cell genes, and lack of expression of other lineage markers. Ultimately, analysis must be conducted at the single cell level using combinations of morphology, immunohistochemistry, and in situ hybridization localization analysis of cell type-restricted markers. Integration and region- and cell type-specific markers must be employed to assess integration of transplanted cells in combination with functional measurements.

When the particular combinations of growth factors, extracellular matrix, ions, signaling molecules and proteases that characterize individual tissue stem cell niches ${ }^{161,162}$ are identified, it should be possible to employ for example, biosynthetic "neo-tissues" 163 to create region specific combinations of cells and requisite growth factors, proteases, and antibodies to promote successful integration of these amazing cells.

\section{ACKNOWLEDGMENTS}

Supported by National Institutes of Health grant NS39438.

\section{REFERENCES}

1. Dewey MJ, Martin DW Jr, Martin GR, Mintz B. Mosaic mice with 
teratocarcinoma -derived mutant cells deficient in hypoxanthine phosphoribosyltransferase. Proc Natl Acad Sci USA 1977;74: 5564-8.

2. Stewart TA, Mintz B. Successive generations of mice produced from an established culture line of euploid teratocarcinoma cells. Proc Natl Acad Sci USA 1981;78:6314-8.

3. Martin GR, Evans MJ. Multiple differentiation of clonal teratocarcinoma stem cells following embryoid body formation in vitro. Cell 1975; 6:467-74.

4. Martin GR. Teratocarcinomas as a model system for the study of embryogenesis and neoplasia. Cell 1975;5:229-43.

5. Martin GR. Teratocarcinomas and mammalian embryogenesis. Science 1980;209:768-76.

6. Rudnicki MA, McBurney MW. Cell culture methods and induction of differentiation of embryonal carcinoma cell lines. In: Robertson EJ, editor. Teratocarcinomas and embryonic stem cells, a practical approach. Oxford: IRL Press, 1987:19-49.

7. Matsui Y, Zsebo K, Hogan BLM. Derivation of pluripotential embryonic stem cells from murine primordial germ cells in culture. Cell 1992;70:841-7.

8. Resnick JL, Bixler LS, Cheng L, Donovan PL. Long-term proliferation of mouse primordial germ cells in culture. Nature 1992; 359: $550-1$.

9. Stewart CL, Gadi I, Bhatt H. Stem cells from primordial germ cells can reenter the germ line. Dev Biol 1994;161:626-8.

10. Labosky PA, Barlow DP, Hogan BLM. Mouse embryonic germ (EG) cell lines: transmission through the germline and differences in the methylation imprint of insulin-like growth factor 2 receptor (Igf2r) gene compared with embryonic stem (ES) cell lines. Development 1994; 120:3197-204.

11. Shamblott MJ, Axelman J, Wang S, Bugg EM, Littlefield JW, Donovan PJ, Blumenthal PD, Huggins GR, Gearhart JD. Derivation of pluripotent stem cells from cultured human primordial germ cells. Proc Natl Acad Sci USA 1998;95:13726-31.

12. Shamblott MJ, Axelman J, Littlefield JW, Blumenthal PD, Huggins GR, Cui Y, Cheng L, Gearhart JD. Human embryonic germ cell derivatives express a broad range of developmentally distinct markers and proliferate extensively in vitro. Proc Natl Acad Sci USA 2001;98:113-8.

13. Rohwedel J, Sehlmeyer U, Shan J, Meister A, Wobus AM. Primordial germ cell-derived mouse embryonic germ (EG) cells in vitro resemble undifferentiated stem cells with respect to differentiation capacity and cell cycle distribution. Cell Biol Int 1996;20: 579-87.

14. Evans MJ, Kaufman MH. Establishment in culture of pluripotential cells from mouse embryos. Nature 1981;292:154-6.

15. Martin GR. Isolation of a pluripotent cell line from early mouse embryos cultured in medium conditioned by teratocarcinoma stem cells. Proc Natl Acad Sci USA 1981;78:7634-8.

16. Brook FA, Gardner RL. The origin and efficient derivation of embryonic stem cells in the mouse. Proc Natl Acad Sci USA 1997; 94:5709-12.

17. Prelle K, Vassiliev IM, Vassilieva SG, Wolf E, Wobus AM. Establishment of pluripotent cell lines from vertebrate species-present status and future prospects. Cells Tissues Organs 1999;165:220-36.

18. Thomson JA, Itskovitz-Eldor J, Shapiro SS, Waknitz MA, Swiergiel JJ, Marshall VS, Jones JM. Embryonic stem cell lines derived from human blastocysts. Science 1998;282:1145-7.

19. Reubinoff BE, Pera MF, Fong CY, Trounson A, Bongso A. Embryonic stem cell lines from human blastocysts: somatic differentiation in vitro. Nat Biotech 2000;18:399-404.

20. Clarke DL, Johansson CB, Wilbertz J, Veress B, Nilsson E, Karlstrom H, Lendahl U, Frisen J. Generalized potential of adult neural stem cells. Science 2000;288:1660-3.

21. Bradley A, Evans M, Kaufman MH, Robertson E. Formation of germ line chimeras from embryo-derived teratocarcinoma cell lines. Nature 1984;309:255-6.
22. Amit M, Carpenter MK, Inokuma MS, Chiu CP, Harris CP, Waknitz MA, Itskovitz-Eldor J, Thomson JA. Clonally derived human embryonic stem cell lines maintain pluripotency and proliferative potential for prolonged periods of culture. Dev Biol 2000;227: 271-8.

23. Savatier P, Lapillonne H, van Grunsven LA, Rudkin BB, Samarut J. Withdrawal of differentiation inhibitory activity/leukemia inhibitory factor up-regulates D-type cyclins and cyclin-dependent kinase inhibitors in mouse embryonic stem cells. Oncogene 1996; 12:309-22.

24. Hogan BLM, Tilley R. In vitro culture and differentiation of normal mouse blastocysts. Nature 1977;265:626-9.

25. Gardner RL. The initial phase of embryonic patterning in mammals. Int Rev Cytol 2001;203:233-90.

26. Morrisey EE, Tang Z, Sigrist K, Lu MM, Jiang F, Ip HS, Parmacek MS. GATA6 regulates HNF4 and is required for differentiation of visceral endoderm in the mouse embryo. Genes Dev 1998;12: 3579-90.

27. Koutsourakis M, Langeveld A, Patient R, Beddington R, Grossveld F. The transcription factor GATA6 is essential for early extraembyonic development. Development 1999;126:723-32.

28. Takeda K, Noguchi K, Shi W, Tanaka T, Matsumoto M, Yoshida N, Kishimoto T, Akira S. Targeted disruption of the mouse Stat3 gene leads to early embryonic lethality. Proc Natl Acad Sci USA 1997; 94:3801-4.

29. Doetschman TC, Eistetter H, Katz M, Schmidt W, Kemler R. The in vitro development of blastocyst-derived embryonic stem cell lines: formation of visceral yolk sac, blood islands and myocardium. J Embyol Exp Morph 1985;87:27-45.

30. O'Shea KS. Neural diferentation of embryonic stem cells. In: Zigova T, Sanchez-Ramos J, editors. Neural stem cells: methods and protocols. Totowa, NJ, Humana Press, 2002. In press.

31. Coucouvanis E, Martin GR. Signals for death and survival: a twostep mechanism for cavitation in the vertebrate embyo. Cell 1995; 83:279-87.

32. Li X, Chen Y, Scheele S, Arman E, Haffner-Krausz R, Ekblom P, Lonai P. Fibroblast growth factor signaling and basement membrane assembly are connected during epithelial morphogenesis of the embryoid body. J Cell Biol 2001;153:811-22.

33. Gajovic S, St Onge L, Yokota Y, Gruss P. Retinoic acid mediates Pax6 expression during in vitro differentiation of embryonic stem cells. Differentiation 1997;62:187-92.

34. Desbaillets I, Ziegler U, Groscurth P, Gassman M. Embryoid bodies: an in vitro model of mouse embryogenesis. Exp Physiol 2000; 85:645-51.

35. Leahy A, Xiong J-W, Kuhnert F, Stuhlmann H. Use of developmental marker genes to define temporal and spatial patterns of differentiation during embryoid body formation. J Exp Zool 1999;284:67-81.

36. Gassman M, Fandrey J, Bichet S, Wartenberg M, Marti HH, Bauer $\mathrm{C}$, Wenger RH, Acker H. Oxygen supply and oxygen-dependent gene expression in differentiating embryonic stem cells. Proc Natl Acad Sci USA 1996;93:2867-72.

37. Lee S-H, Lumelsky N, Studer L, Auerbach JM, McKay RD. Efficient generation of midbrain and hindbrain neurons from mouse embryonic stem cells. Nature Biotechnol 2000;18:675-9.

38. Mountford P, Nichols J, Zevnik B, O'Brien C, Smith A. Maintenance of pluripotential embryonic stem cells by stem cell selection. Reprod Fertil Dev 1998;10:527-33.

39. Eiges R, Schuldiner M, Drukker M, Yanuka O, Itskovitz-Eldor J, Benvenisty N. Establishment of human embryonic stem celltransfected clones carrying a marker for undifferentiated cells. Curr Biol 2001;11:514-8.

40. Chambon P. A decade of molecular biology of retinoic acid receptors. FASEB J 1996;10:940-54.

41. Hogan BL, Thaller C, Eichele G. Evidence that Hensen's node is a site of retinoic acid synthesis. Nature 1992;359:237-41.

42. Tickle C, Alberts B, Wolpert L, Lee J. Local application of retinoic 
acid to the limb bud mimics the action of the polarizing region. Nature 1982;296:564-6.

43. Edwards MKS, McBurney MW. The concentration of retinoic acid determines the differentiated cell types formed by a teratocarcinoma cell line. Dev Biol 1983;98:187-91.

44. Breier G, Bucan M, Francke U, Colberg-Poley AM, Gruss P. Sequential expression of murine homeo box genes during F9 EC cell differentiation. EMBO J 1986;5:2209-15.

45. Boncinelli E, Simeone A, Acampora D, Mavilio F. HOX gene activation by retinoic acid. Trends Genet 1991;7:329-34.

46. Rohwedel J, Guan K, Wobus A. Induction of cellular differentiation by retinoic acid in vitro. Cells Tissues Organs 1999;165:190-202.

47. Dani C, Smith AG, Dessolin S, Leroy P, Staccini L, Villageois P, Dairmont C, Ailhaud G. Differentiation of embryonic stem cells into adipocytes in vitro. J Cell Sci 1997;110:1279-85.

48. Fraichard A, Chassande O, Bilbaut G, Dehay C, Savatier P, Samarut J. In vitro differentiation of embryonic stem cells into glial cells and functional neurons. J Cell Sci 1995;108:3181-8.

49. van Inzen WG, Peppelenbosch MP, van den Brand MWM, Tertoolen LGJ, deLaat SW. Neuronal differentiation of embryonic stem cells. Biochem Biophys Acta 1996;1312:21-6.

50. Bain G, Kitchens D, Yao M, Huettner JE, Gotlieb DI. Embryonic stem cells express neuronal properties in vitro. Dev Biol 1995; 168:342-57.

51. Schuldiner M, Eiges R, Eden A, Yanuka O, Itskovitz-Eldor J, Goldstein RS, Benvenisty N. Induced neuronal differentiation of human embryonic stem cells. Brain Res;2001;913:201-5.

52. Schuldiner M, Yanuka O, Itskovitz-Eldor J, Melton DA, Benvenisty N. Effects of eight growth factors on the differentiation of cells derived from human embryonic stem cells. Proc Natl Acad Sci USA 2000;97:11307-12.

53. Dinsmore J, Ratliff J, Deacon T, Pakzaban P, Jacoby D, Galpern $\mathrm{W}$, Isacson O. Embryonic stem cells differentiated in vitro as a novel source of cells for transplantation. Cell Transpl 1996;5: $131-43$.

54. Lako M, Lindsay S, Lincoln J, Cairns PM, Armstrong L, Hole N. Characterization of Wnt gene expression during the differentiation of murine embryonic stem cells in vitro: role of Wnt3 in enhancing haematopoietic differentiation. Mech Dev 2001;103:49-59.

55. Lassar AB, Paterson BM, Weintraub H. Transfecion of a DNA locus that mediates the conversion of $10 \mathrm{~T} 1 / 2$ fiboblasts to myoblasts. Cell 1986;47:649-56.

56. Thomas KR, Capecchi MR. Site-directed mutagenesis by gene targeting in mouse embryo-derived stem cells. Cell 1987;51:50312.

57. Ye P, Xing Y, Dai Z, D'Ercole AJ. In vivo actions of insulin-like growth factor-I (IGF-I) on cerebellum development in transgenic mice: evidence that IGF-I increases proliferation of granule cell progenitors. Brain Res Dev Brain Res 1996;95:44-54.

58. Pearson BE, Choi TK. Expression of the human $\beta$-amyloid precursor protein gene from a yeast artificial chromosome in transgenic mice. Proc Natl Acad Sci USA 1993;90:10578-82.

59. Boulter CA, Aguzzi A, Williams RL, Wagner EF, Evans MJ, Beddingon R. Expression of v-src induces aberrant development and twinning in chimaeric mice. Development 1991;111:357-66.

60. Friedrich G, Soriano P. Promoter traps in embryonic stem cells: a genetic screen to identify and mutate developmental genes in mice. Genes Dev 1991;5:1513-23.

61. Mitchell KJ, Pinson KI, Kelly OG, Brennan J, Zupicich J, Scherz P, Leighton PA, Goodrich LV, Lu X, Avery BJ, Tate P, Dill K, Pangillian E, Wakenight P, Tessier-Lavigne M, Skarnes WC. Functional analysis of secreted and transmembrane proteins critical to mouse development. Nat Genet 2001;28:241-9.

62. Du Z, Cong H, Yao Z. Identification of putative downstream genes of Oct- 4 by suppression-subtractive hybridization. Biochem Biophys Res Commun 2001;282:701-6.

63. Hollnagel A, Oehlmann V, Heymer J, Rüther U, Nordheim A. Id genes are direct targets of bone morphogenetic protein induction in embryonic stem cells. J Biol Chem 1999;274:19838-45.

64. Shen MH, Yang J, Loupart M-L, Smith A, Brown W. Human minichromosomes in mouse embryonal stem cells. Hum Mol Genet 1997;6:1375-82.

65. Mortensen RM, Conner DA, Chao S, Geisterfer-Lowrance AAT, Seidman JG. Production of homozygous mutant ES cells with a single targeting construct. Mol Cell Biol 1992;12:2391-5.

66. Metzler M, Chen N, Helgason CD, Graham RK, Nichol K, McCutcheon K, Nasir J, Humphries RK, Raymond LA, Hayden MR. Life without huntingtin: normal differentiation into functional neurons. J Neurochem 1999;72:1009-18.

67. Hadjantonakis AK, Gertsenstein M, Ikawa M, Okabe M, Nagy A. Generating green fluorescent mice by germline transmission of green fluorescent ES cells. Mech Dev 1998;76:79-90.

68. Kolossov E, Fleischmann BK, Liu Q, Bloch W, Viatchenko-Karpinski S, Manzke O, Ji GJ, Bohlen H, Addicks K, Hescheler J. Functional characteristics of ES cell-derived cardiac precursor cells identified by tissue-specific expression of the green fluorescent protein. J Cell Biol 1998;143:2045-56.

69. Pratt T, Sharp L, Nichols J, Price DJ, Mason JO. Embryonic stem cells and transgenic mice ubiquitously expressing a tau-tagged green fluorescent protein. Dev Biol 2000;228:19-28.

70. O'Shea KS. Neuronal differentiation of mouse embryonic stem cells: lineage selection and forced differentiation paradigms. Blood Cells Mol Dis 2001;27:705-12.

71. McWhir J, Schnieke AE, Ansell R, Wallace H, Colman A, Scott AR, Kind AJ. Selective ablation of differentiated cells permits isolation of embryonic stem cell lines from murine embryos with a non-permissive genetic background. Nat Genet 1996;14:223-6.

72. Klug MG, Soonpaa MH, Koh GY, Field LJ. Genetically selected cardiomyocytes from differentating embryonic stem cells form stable intracardiac grafts. J Clin Invest 1996;98:216-25.

73. Li M, Pevny L, Lovell-Badge R, Smith A. Generation of purified neural precursors from embryonic stem cells by lineage selection. Curr Biol 1998;8:971-4.

74. Pevny LH, Sockanathan S, Placzek M, Lovell-Badge R. A role for Sox1 in neural determination. Development 1998;125:1967-78.

75. O'Shea KS, Aton S, D'Amato CJ, Gratsch TE. Embryonic stem cell derived neuroepithelial progenitor cells. Soc Neurosci 1999;24: 328 [Abstract].

76. Lendahl U, Zimmerman LB, McKay RDG. CNS stem cells express a new class of intermediate filament protein. Cell 1990;60:585-95.

77. Wiles MV, Johansson BM. Embryonic stem cell development in a chemically defined medium. Exp Cell Res 1999;247:241-8.

78. Soria B, Roche E, Berna G, Leon-Quinto T, Reig JA, Martin F. Insulin-secreting cells derived from embryonic stem cells normalize glycemia in streptozotocin-induced diabetic mice. Diabetes 2000;49:157-62.

79. Dekel I, Magal Y, Pearson-White S, Emerson CP, Shani M. Conditional conversion of ES cells to skeletal muscle by an exogenous myoD1 gene. New Biol 1992;4:217-24.

80. Rohwedel J, Horák V, Hebrok M, Füchtbauer E-M, Wobus AM. $M$-twist expression inhibits mouse embryonic stem cell-derived myogenic differentiation in vitro. Exp Cell Res 1995;220:92-100.

81. Grépin C, Nemer G, Nemer M. Enhanced cardiogenesis in embryonic stem cells overexpressing the GATA-4 transcription factor. Development 1997;124:2387-95.

82. Grépin C, Robitaille L, Antakly T, Nemer M. Inhibition of transcription factor GATA-4 expression blocks in vitro cardiac muscle differentiation. Mol Cell Biol 1995;15:4095-102.

83. Allen ND, Barton SC, Hilton K, Norris ML, Surani MA. A functional analysis of imprinting in parthenogenetic embryonic stem cells. Development 1994;120:1473-82.

84. Mann JR, Stewart CL. Development to term of mouse androgenetic aggregation chimeras. Development 1991;113:1325-33.

85. McKarney LA, Overall ML, Dziadek M. Myogenesis in cultures of 
uniparental mouse embryonic stem cells: differing patterns of expression of myogenic regulatory factors. Int J Dev Biol 1997; 41:485-90.

86. Prelle K, Wobus AM, Krebs O, Blum WF, Wolfe E. Overexpression of insulin-like growth factor-II in mouse embryonic stem cells promotes myogenic differentiation. Biochem Biophys Res Com 2000;277:631-8.

87. Fan Y, Melhem MF, Chaillet JR. Forced expression of the homeobox - containing gene Pem blocks differentiation of embryonic stem cells. Dev Biol 1999;210:481-96.

88. Niwa H, Miyazaki J-I, Smith AG. Quantitative expression of Oct$3 / 4$ defines differentiation, dedifferentiation or self-renewal of ES cells. Nat Genet 2000;24:372-6.

89. Palmieri SL, Peter W, Hess H, Scholer HR. Oct-4 transcription factor is differentially expressed in the mouse embryo during establishment of the first two extraembryonic cell lineages involved in implantation. Dev Biol 1994;166:259-67.

90. Buttery LD, Bourne S, Xynos JD, Wood H, Hughes FJ, Hughes SP, Episkopou V, Polak JM. Differentiation of osteoblasts and in vitro bone formation from murine embryonic stem cells. Tissue Eng 2001;7:89-99.

91. Phillips BW, Belmonte N, Vernochet C, Ailhaud G, Dani C. Compactin enhances osteogenesis in murine embryonic stem cells. Biochem Biophys Res Commun 2001;284:478-84.

92. Kramer J, Hegert C, Guan K, Wobus AM, Muller PK, Rohwedel J. Embryonic stem cell-derived chondrogenic differentiation in vitro: activation by BMP-2 and BMP-4. Mech Dev 2000;92:193205.

93. Yamashita J, Itoh H, Hirashima M, Ogawa M, Nishikawa S, Yurugi T, Naito M, Kakao K, Nishikawa S. Flt-1 positive cells derived from embyonic stem cells serve as vascular progenitors. Nature 2000;408:92-6.

94. Rohwedel J, Maltsev V, Bober E, Arnold HH, Hescheler J, Wobus AM. Muscle cell differentiation of embryonic stem cells reflects myogenesis in vivo: developmentally regulated expression of myogenic determination genes and functional expression of ionic currents. Dev Biol 1994;164:87-101.

95. Maltsev VA, Rohwedel J, Hescheler J, Wobus AM. Embryonic stem cells differentiate in vitro into cardiomyocytes representing sinusnodal, atrial and ventricular cell types. Mech Dev 1993;44: $41-50$.

96. Nakano T, Kodama H, Honjo T. In vitro development of primitive and definitive erythrocytes from different precursors. Science 1996;272:722-4.

97. Nishikawa SI, Nishikawa S, Hirashima M, Matsuyoshi N, Kodama H. Progressive lineage analysis by cell sorting and culture identifies FLK1 $(+)$ ve-cadherin $(+)$ cells at a diverging point of endothelial and hemopoietic lineages. Development 1998;125:1747-57.

98. Tsai M, Wedemeyer J, Ganiatsas S, Tam SY, Zon LI, Galli SJ. In vivo immunological function of mast cells derived from embryonic stem cells: an approach for the rapid analysis of even embryonic lethal mutations in adult mice in vivo. Proc Natl Acad Sci USA 2000;97:9186-90.

99. Hemmi H, Okuyama H, Yamane T, Nishikawas, Nakano T, Yamazaki H, Kunisada T, Hayashi S. Temporal and spatial localization of osteoclasts in colonies from embryonic stem cells. Biochem Biophys Res Commun 2001;280:526-34.

100. Gualandris A, Annes JP, Arese M, Noguera I, Jurukovski V, Rifkin DB. The latent transforming growth factor-beta-binding protein1 promotes in vitro differentiation of embryonic stem cells into endothelium. Mol Biol Cell 2000;11:4295-308.

101. Risau W, Sariola H, Zerwes HG, Sasse J, Ekblom P, Kemler R, Doetschman T. Vasculogenesis and angiogenesis in embryonicstem-cell-derived embryoid bodies. Development 1988;102:471-8.

102. Bagutti C, Wobus AM, Fässler R, Watt FM. Differentiation of embryonal stem cells into keratinocytes: comparison of wild-type and $\beta 1$ integrin-deficient cells. Dev Biol 1996;179:184-96.
103. Procacci M, Virolle T, Cailleteau L, Ortonne JP, Aberdam D. Differentiation of embryonic stem cells into keratinocytes. J Invest Dermatol 2000;15:518 [abstract].

104. Yamane T, Hayashi S-I, Mizoguchi M, Yamazaki H, Kunisada T. Derivation of melanocytes from embryonic stem cells in culture. Dev Dyn 1999;216:450-8 [abstract].

105. Fairchild PJ, Brook FA, Gardner RL, Graca L, Strong V, Tone Y, Tone M, Nolan KF, Waldmann H. Directed differentiation of dendritic cells from mouse embryonic stem cells. Curr Biol 2000; 10:1515-8.

106. Deacon T, Dinsmore J, Constantini LC, Ratliff J, Isacson O. Blastula-stage stem cells can differentiate into dopaminergic and serotonergic neurons after transplantation. Exp Neurol 1998;149: $28-41$.

107. Strubing C, Ahnert-Hilger G, Shan J, Wiedenmann B, Hescheler J, Wobus AM. Differentiation of pluripotent embryonic stem cells into the neuronal lineage in vitro gives rise to mature inhibitory and excitatory neurons. Mech Dev 1995;53:275-87.

108. Brüstle O, Jones KN, Learish RD, Karram K, Choudhary K, Wiestler OD, Duncan ID, McKay RD. Embryonic stem cell-derived glial precursors: a source of myelinating transplants. Science 1999;285: $754-6$.

109. Liu S, Qu Y, Stewart TJ, Howard MJ, Chakrabortty S, Holekamp TF, McDonald JW. Embryonic stem cells differentiate into oligodendrocytes and myelinate in culture and after spinal cord transplantation. Proc Natl Acad Sci USA 2000;97:6126-31.

110. Hamazaki T, Iiboshi Y, Oka M, Papst PJ, Meacham AM, Zon LI, Terada N. Hepatic maturation in differentiating embryonic stem cells in vitro. FEBS Lett 2001;497:15-9.

111. Jacobson L, Kahan B, Djamali A, Thomson J, Odorico JS. Differentiation of endoderm derivatives, pancreas and intestine, from rhesus embryonic stem cells. Transplant Proc 2001;33:674.

112. Odorico JS, Kaufman DS, Thomson JA. Multilineage differentiation from human embryonic stem cell lines. Stem Cells 2001;19: 193-204.

113. Lumelsky N, Blondel O, Laeng P, Velasco I, Ravin R, McKay R. Differentiation of embryonic stem cells to insulin-secreting structures similar to pancreatic islets. Science 2001;292:1389-94.

114. Bottenstein JE, Sato GH. Growth of rat neuroblastoma cell line in serum-free supplemented media. Proc Natl Acad Sci USA 1979; 76:514-7.

115. NIH. Stem cells: scientific progress and future research directions. 2001. Available from: URL: http://www.nih.gov/news/stemcell/sci report.htm.

116. O'Shea KS. Embryonic stem cell models of development. Anat Rec 1999;257:32-41.

117. Rathjen PD, Lake J, Whyatt LM, Bettess MD, Rathjen J. Properties and uses of embryonic stem cells: prospect for application to human biology and gene therapy. Reprod Fertil Dev 1998;10:31-47.

118. Wobus AM, Guan K, Pich U. In vitro differentiation of embryonic stem cells and analysis of cellular phenotypes. Meth Mol Biol 2001;153:263-86.

119. Weinstein DC, Hemmati-Brivanlou A. Neural induction. Annu Rev Cell Dev Biol 1999;15:411-33.

120. Gratsch TE, O'Shea KS. Noggin and neurogenesis in embryonic stem cells. FASEB J 1998;12:974 [Abstract].

121. Tropepe V, Hitoshi S, Sirard C, Mak TW, Rossant J, vanderKooy D. Direct neural fate specification from embryonic stem cells. a primitive mammalian neural stem cell stage acquired through a default mechanism. Neuron 2001;30:65-78.

122. Kawasaki H, Mizuseki K, Nishikawa S, Kaneko S, Kuwana Y, Nakanishi S, Nishikawa S-I, Sasai Y. Induction of midbrain dopaminergic neurons from ES cells by stromal cell-derived inducing activity. Neuron 2000;28:31-40E.

123. Finley MF, Devata S, Huettner J. BMP-4 inhibits neural differentiation of murine embryonic stem cells. J Neurobiol 1999;40:271-87.

124. Rohwedel J, Guan K, Zuschratter W, Jin S, Ahner-Hilger G, Furst 
D, Fassler R, Wobus AM. Loss of beta1 integrin function results in a retardation of myogenic, but an acceleration of neuronal; differentiation of embryonic stem cells in vitro. Dev Biol 1998; 201:167-84.

125. Turksen K, Troy T-C. Claudin-6: a novel tight junction molecule is developmentally regulated in mouse embryonic epithelium. Dev Dyn 2001;222:292-300.

126. Assady S, Maor G, Amit M, Itskovitz-Eldor J, Skorecki KL, Tzukerman M. Insulin production by human embryonic stem cells. Diabetes 2001;50:1691-7.

127. Levinson-Dushnik M, Benvenisty N. Involvement of hepatocyte nuclear factor 3 in endoderm differentiation of embryonic stem cells. Mol Cell Biol 1997;17:3817-22.

128. Rohwedel J, Kleppish T, Pich U, Guan K, Jin S, Zuschratter W, Hopf C, Hoch W, Hescheler J, Witzemann V, Wobus AM. Formation of postsynaptic-like membranes during differentiation of embryonic stem cells in vitro. Exp Cell Res 1998;239:214-25.

129. Hole N. Embryonic stem cell-derived haematopoiesis. Cells Tissues Organs 1999;165:181-9.

130. Hole N, Graham GJ, Menzel U, Ansell JD. A limited temporal window for the derivation of multilineage repopulating hematopoieic progenitors during embryonal stem cell differentiation in vitro. Blood 1996;88:1266-76.

131. Lazner F, Kola I, Stadler E, Elefanty AG. Embryonic stem cells in the study of hematopoiesis. Meth Mol Biol 2001;158:287-300.

132. Keller G, Kennedy M, Papayannopoulou T, Wiles MV. Hematopoietic commitment during embryonic stem cell differentiation in culture. Mol Cell Biol 1993;13:473-86.

133. Potocnik AJ, Kohler H, Eichmann K. Hemato-lymphoid in vivo reconstitution potential of subpopulations derived from in vitro differentiated embryonic stem cells. Proc Natl Acad Sci USA 1997; 94:10295-300.

134. Palacios R, Golunski E, Samaridis J. In vitro generation of hematopoietic stem cells from an embryonic stem cell line. Proc Natl Acad Sci USA 1995;92:7530-4.

135. Pinto do OP, Kolterud A, Carlsson L. Expression of the LIMhomeobox gene LH2 generates immortalized steel factor-dependent multipotent hematopoietic precursors. EMBO J 1998;17: $5744-56$.

136. Cheng J, Du C, Lavau C, Chen S, Tong J, Chen BP, Scollay R, Hawley RG, Hill B. Sustained gene expression in retrovirally transduced, engrafting human hematopoieic stem cells and their lympho-myeloid progeny. Blood 1998;92:83-92

137. Johe KK, Hazel TG, Muller T, Dugich-Djordjevic MM, McKay RG. Single factors direct the differentiation of stem cells from the fetal and adult nervous system. Genes Dev 1996;10:3129-40.

138. Okabe SS, Forsberg-Nilsson K, Spiro AC, Segal M, McKay RDG. Development of neuronal precursor cells and functional postmitotic neurons from embryonic stem cells in vitro. Mech Dev 1996; 59:89-102.

139. Ye W, Shimamura K, Rubenstein JLR, Hynes MA, Rosenthal A. FGF and Shh signals control dopaminergic and serotonergic cell fate in the anterior neural plate. Cell 1998;93:755-66.

140. Renoncourt Y, Carroll P, Filippi P, Arce V, Alonso S. Neurons derived in vitro from ES cells express homeoproteins characteristic of motoneurons and interneurons. Mech Dev 1998;79:185-97.

141. Benninger Y, Marino S, Hardegger R, Weissman C, Aguzzi A, Brandner S. Differentiation and histological analysis of embryonic stem cell-derived neural transplants in mice. Brain Pathol 200;10: 330-41.

142. Raff MC, Miller RH, Noble M. A glial progenitor cell that develops in vitro into an astrocyte or an oligodendrocyte depending on culture medium. Nature 1983;303:390-6.
143. McDonald JW, Liu XZ, Qu Y, Liu S, Mickey SK, Turetsky D, Gottlieb DI, Choi DW. Transplanted embryonic stem cells survive, differentiate and promote recovery in injured rat spinal cord. Nat Med 1999;5:1410-2.

144. Gökhan S, Mehler MF. Basic and clinical neuroscience applications of embryonic stem cells. Anat Rec 2001;265:142-56.

145. Lorincz MT, O'Shea KS, Dettlof PD, Albin RL. Neuronally differentiated ES cells as a Huntington's Disease model. Soc Neurosci Abstract 2001;27. Program No. 99.10.

146. Moore KA, Pytowski B, Witte L, Hicklin D, Lemischka IR. Hematopoietic acitivity of a stromal cell transmembrane protein containing epidermal growth factor-like repeat motifs. Proc Natl Acad Sci USA 1997;94:4011-6.

147. Belaoussoff M, Farrington SM, Baron MH. Hematopoietic induction and respecification of A-P identity by visceral endoderm signaling in the mouse embryo. Development 1998;125:5009-18.

148. Smith AG, Hooper ML. Buffalo rat liver cells produce a diffusible activity which inhibits the differentiation of murine embryonal carcinoma and embryonic stem cells. Dev Biol 1987;121:1-9.

149. Solter D, Knowles BB. Monoclonal antibody defining a stagespecific mouse embryonic antigen (SSEA-1). Proc Natl Acad Sci USA 1978;75:5565-9.

150. Pesce M, Scholer HR. Oct-4: gatekeeper in the beginnings of mammalian development. Stem Cells 2001;19:271-8.

151. Rogers MB, Hosler BA, Gudas LJ. Specific expression of a retinoic acid-regulated, zinc-finger gene, REX-1, in preimplantation embryos, trophoblast and spermatocytes. Development 1991;113: $815-24$.

152. Chong JA, Tapia-Ramirez J, Kim S, Toledo-Aral JJ, Zheng Y, Boutros MC, Altshuller YM, Frohman MA, Kraner SD, Mandel G. REST: a mammalian silencer protein that restricts sodium channel gene expression to neurons. Cell 1995;80:949-57.

153. Voss AK, Thomas T, Petrou P, Anastassiadis K, Scholer H, Gruss $\mathrm{P}$. Taube nuss is a novel gene essential for the survival of pluripotent cells of early mouse embryos. Development 2000;127:5449-61.

154. Xu C, Inokuma MS, Denham J, Golds K, Kundu P, Gold JD, Carpenter MK. Feeder-free growth of undifferentiated human embryonic stem cells. Nat Biotech 2001;19:971-4.

155. Gearhart JD. New potential for human embryonic stem cells. Science 1998;282:1061-2.

156. Grusby MJ, Auchincloss H Jr, Lee R, Johnson RS, Spencer JP, Zijlstra M, Jaenisch R, Papaioannou VE, Glimcher LH. Mice lacking major histocompatibility complex class I and class II molecules. Proc Natl Acad Sci USA 1993;90:3913-7.

157. Kawase E, Yamazaki Y, Yagi T, Yanagimachi R, Pedersen RA. Mouse embryonic stem (ES) cell lines established from neuronal cellderived cloned blastocysts. Genesis 2000;28:156-63.

158. Wakayama T, Tabar V, Rodriguez I, Perry AC, Studer L, Mombaerts P. Differentiation of embyonic stem cell lines generated from adult somatic cells by nuclear transfer. Science 2001;292:740-3.

159. Wilmut I, Schnieke AE, McWhir J, Kind AJ, Campbell KH. Viable offspring derived from fetal and adult mammalian cells. Nature 1997;385:810-3.

160. Kang Y-K, Koo D-B, Park J-S, Choi Y-H, Chung A-S, Lee K-K, Han Y-M. Aberrant methylation of donor genome in cloned bovine embryos. Nat Genet 2001;28:173-7.

161. Schofield $R$. The relationship between the spleen colony-forming cell and the haemopoietic stem cell. Blood Cells 1978;4:7-25.

162. Watt FM, Hogan BLM. Out of Eden: stem cells and their niches. Science 2000;287:1427-30.

163. Mahoney MJ, Saltzman WM. Transplantation of brain cells assembled around a programmable synthetic microenvironment. Nat Biotech 2001;19:934-9. 